Results Duration of hospitalization of the I group was $6.15 \pm 0.24$ days, the II group - 5.29 \pm 0.22 days, the III group - $4.26 \pm 0.25$ days $(\mathrm{P}<0.001)$. In children of the I group $73.7 \%$ were recovered, in children of the II group - $78.2 \%$, and in children of the III group - $85.7 \%$ of children.

Conclusions The minim invasive method of endoscopical surgery in the proper modification made possible the more rapid recovery from the inflammatory process in the patients with recurrent and chronic sinusitis.

\section{CLINICAL AND ULTRASOUND EXAMINATION AFTER UNILATERAL ORCHIOPEXY}

doi:10.1136/archdischild-2012-302724.1583

${ }^{1} \mathrm{~J}$ de Laffolie, ${ }^{2} \mathrm{~S}$ Turial, ${ }^{2} \mathrm{R}$ Freudenberger, ${ }^{2} \mathrm{~V}$ Engel, ${ }^{2} \mathrm{~F}$ Schier. ${ }^{1}$ General Pediatrics and Neonatology, University of Gießen, Giessen; 2Department of Pediatric Surgery, University of Mainz, Mainz, Germany

Aim To compare testis volume and ultrasound texture post unilateral orchiopexy with the other side.

Methods Clinical re-examination and ultrasound measurement of testicle volume and echostructure were performed in 99 children after unilateral orchiopexy, performed between 2003 and 2007.

Results Intraoperatively, 30 testis were described as hypoplastic. further 5 patients displayed pathologic funicular structures.

On Follow-up clinical exam, 45 patients displayed a small or atrophic testis on the side of surgery. In 10 patients, the testis was described as bigger on the side of surgery.

On ultrasound, 65 patients had similar pictures on the side of surgery compared to the other side. In the group $<2$ years, volume was measured as $0.2 \mathrm{ml} \pm 0.1 \mathrm{ml}$ vs $0.4 \mathrm{ml} \pm 0.2 \mathrm{ml}$ contralaterally $(n=10)$. In the age group 3 to 5 years volume was measured $0.4 \mathrm{ml} \pm 0.2 \mathrm{ml}$ vs $0.6 \mathrm{ml} \pm 0.3 \mathrm{ml}(\mathrm{n}=41)$, in the group $6-10$ years $0.4 \mathrm{ml} \pm 0.2 \mathrm{ml}$ vs $0.5 \mathrm{ml} \pm 0.3 \mathrm{ml}(\mathrm{n}=28)$ and in 11 to 17 year-olds volume was $3.1 \pm 2.7 \mathrm{ml}$ vs $3.9 \pm 3.8 \mathrm{ml}(\mathrm{n}=11)$.

Correlation of age at surgery and postsurgery volume difference between testes was $r=0.6$ (Pearson). In an univariate variance analysis a mild influence was found by age at surgery, inguinal hernia or re-operation.

Conclusion After orchiopexy a hypotrophic testis on the side of surgery was found in an unexpectedly high proportion. Ultrasound added valuable data (volume, texture) to the clinical follow-up examination, especially when compared to the contralateral side.

\section{APPLICABILITY OF SIGMOID COLON GRAFT FOR VAGINAL REPLACEMENT (COLOVAGINOPLASTY) AT YOUNG AGE}

doi:10.1136/archdischild-2012-302724.1584

HA Al Abeissy. Obstetric Gynecology, Al Azher University, Cairo, Egypt

Objective To evaluate the applicability, feasibility, complications, short and long term results of vaginoplasty by using sigmoid colon graft with the use of stapler for resuming colonic continuity in children with absent vagina.

Patients and Methods The records of 17 patients, 12 of them had Congenital Adrenal Hyperplasia (CAH), 3 had Androgen Insensitivity Syndrome (AIS) and 2 had vaginal atresia underwent sigmoid graft vaginal reconstruction with the aid of circular stapler during a period of 5 year from 2005 to 2010 were reviewed retrospectively.

Results A neovagina was constructed in 17 patients aged from 1 to 8 years (mean 3 years) during the study period, where sigmoid colon was used in all patients. Hospital stay ranged from 5 to 12 days (mean 7), operative time ranged from 60 to 120 min (mean 75). Complications occurred in 4 patients, introital stenosis in 2 patients, one of them necessitates revision of the introits and 2 cases had wound minor infection. The need for neovaginal dilation was indicated in only 8 out of 17 patients. There was no complications related to bowel anastomosis, No mortality in this group, the cosmetic results were excellent in all cases, with good patient satisfaction.

Conclusion Sigmoid colovaginoplasty appears to be applicable for remedy of vaginal atresia and at any age. It is associated with a less complication rate, the long term results is satisfactory and it seems better technique than skin flaps, especially in girls who doesn't expect sexual activity shortly after surgery.

\section{UNILATERAL VERSUS BILATERAL SURGERY FOR INGUINAL HERNIA IN PREMATURE BOYS: A MULTICENTER FRENCH STUDY ON 966 CASES}

doi:10.1136/archdischild-2012-302724.1585

${ }^{1} \mathrm{O}$ Maillet, ${ }^{1} \mathrm{~S}$ Garnier, ${ }^{2} \mathrm{G}$ Podevin, ${ }^{2} \mathrm{MD}$ Leclair, ${ }^{3} \mathrm{~A}$ Arnaud, ${ }^{3} \mathrm{~B}$ Fremond, ${ }^{4} \mathrm{C}$ Linard, ${ }^{5} \mathrm{R}$ Compagnon, ${ }^{5} \mathrm{~L}$ Fourcade, ${ }^{6} \mathrm{O}$ Jaby, ${ }^{6} \mathrm{M}$ Ponet, ${ }^{7} \mathrm{~A}$ El Ghoneimi, ${ }^{7} \mathrm{~J}$ Cohen, ${ }^{7} \mathrm{~A}$ Bonnard, ${ }^{8} \mathrm{~J}$ Breaud, ${ }^{8} \mathrm{~F}$ Bastiani, ${ }^{8} \mathrm{~J} \mathrm{Kurzenne,}{ }^{9} \mathrm{M}$ Lopez Paredes, ${ }^{9} \mathrm{~F}$ Varlet, ${ }^{10} \mathrm{E}$ Sapin, ${ }^{10} \mathrm{M}$ Lirussi Borgnon, "'S Sibai, "'C Piolat, " ${ }^{11}$ Teklali, ${ }^{12} \mathrm{~L}$ Harper, 'E Sabatier, 'MP Guibal, 'D Forgues, ${ }^{1} \mathrm{H}$ Allal, ${ }^{1} \mathrm{RB}$ Galifer, ${ }^{1} \mathrm{~N}$ Kalfa. ${ }^{1}$ Pediatric Surgery, $\mathrm{CHU}$ Montpellier, Montpellier; ${ }^{2} \mathrm{CHU}$ Nantes, Nantes; ${ }^{3} \mathrm{CHU}$ Rennes, Rennes; ${ }^{4} \mathrm{CHU}$ Brest, Brest; ${ }^{5} \mathrm{CHU}$ Limoges, Limoges; ${ }^{6} \mathrm{CHI}$ Creteil, Créteil; ${ }^{7} \mathrm{APHP}$, Paris; ${ }^{8} \mathrm{CHU}$ Nice, Nice; ${ }^{9} \mathrm{CHU}$ St Etienne, St Etienne; ${ }^{10} \mathrm{CHU}$ Dijon, Dijon; ${ }^{11} \mathrm{CHU}$ Grenoble, Grenoble; ${ }^{12}$ Centre Hospitalier Regional, Saint Denis de La Réunion, France

Background and Aim Bilateral surgery was formerly advocated in premature boys with unilateral inguinal hernia to avoid a metachronous contralateral hernia and the risks of recurrent anesthesia. But the recent progress in pediatric anesthesia and the demonstrated morbidity of herniotomy during the neonatal period on fertility now question this attitude. We aimed to compare the morbidity of preventive bilateral vs elective unilateral herniotomy in premature boys with unilateral hernia and to evaluate the incidence of contralateral metachronous hernia.

Methods Retrospective multicenter analysis of 966 premature boys presenting with unilateral inguinal hernia. 558 infants benefited from unilateral herniotomy and 408 from bilateral herniotomy with a median follow up of 20 months.

\section{Results}

1. The rate of contralateral metachronous hernia after unilateral surgery was $11 \%$ ( $10 \%$ on right vs $13 \%$ on left).

2. Morbidity on the contralateral side was higher in case of preventive bilateral surgery than in metachronous hernia ( $2 \%$ vs $0.2 \% \mathrm{p}=0.003)$, especially for testicular hypotrophy $(0.70 \%$ vs $0.18 \%, p=0.3)$ and secondary cryptorchidism $(1 \%$ vs $0 \%, \mathrm{p}=0.03$ )

3. Comparison between the type anesthesias (general anesthesia versus central block) did not show significant differences depending on the type of care (unilateral or bilateral, planned or emergency).

Conclusion Systematic bilateral herniotomy is unnecessary in almost $90 \%$ of patients and has a higher morbidity than secondary surgery for metachronous hernia. These results, along with the risk of deferential damage and hypofertility reported in later adulthood, justify treating only the symptomatic side in premature boys.

\section{MINOR HYPOSPADIAS: THE "TIP OF THE ICEBERG" OF THE PARTIAL ANDROGEN INSENSITIVITY SYNDROME}

doi:10.1136/archdischild-2012-302724.1586

${ }^{1} \mathrm{~N}$ Kalfa, ${ }^{1} \mathrm{P}$ Philibert, ${ }^{1} \mathrm{~F}$ Audran, ${ }^{2} \mathrm{~A}$ Bashamboo, ${ }^{3} \mathrm{H}$ Lehors, ${ }^{3} \mathrm{M}$ Haddad, ${ }^{3} \mathrm{JM}$ Guys, ${ }^{3} \mathrm{R}$ Reynaud, ${ }^{3} \mathrm{P}$ Alessandrini, ${ }^{4} \mathrm{~K}$ Wagner, ${ }^{4} \mathrm{JY}$ Kurzenne, ${ }^{4} \mathrm{~F}$ Bastiani, ${ }^{4} \mathrm{~J}$ Bréaud, ${ }^{4} \mathrm{~J}$ Valla, ${ }^{3} \mathrm{GM}$ Lacombe, ${ }^{5} \mathrm{M}$ Orsini, $5 \mathrm{JP}$ Daures, ${ }^{1} \mathrm{~F}$ Paris, ${ }^{2} \mathrm{~K}$ McElreavey, ${ }^{1} \mathrm{C}$ Sultan. ${ }^{\prime} \mathrm{CHU}$ Montpellier, Montpellier; ${ }^{2}$ Institut Pasteur, Paris; ${ }^{3} \mathrm{APHM}$, Marseille; ${ }^{4} \mathrm{CHU}$ Nice, Nice; ${ }^{5}$ Université Montpellier 1, Montpellier, France

Background and Aims Alterations in the androgen sensitivity pathway have been identified in severely undermasculinized boys, and mutations of the androgen-receptor gene (AR) are usually 